\title{
"BY THE END OF THIS COURSE YOU SHOULD BE ABLE TO...": TOWARDS CONSTRUCTIVE ALIGNMENT IN THE SLP CURRICULUM
}

Michelle Pascoe and Shajila Singh Division of Communication Sciences and Disorders, University of Cape Town, South Africa

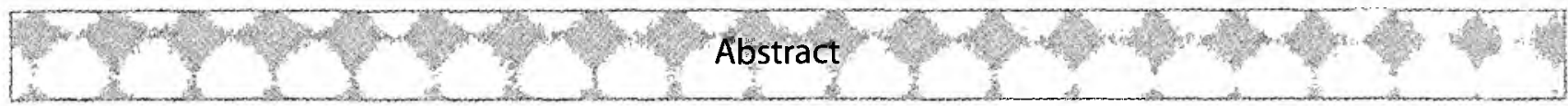

This paperdescribes the way in which constructivealignmentis being implemented in the Speech-language Pathology (SLP) programmeat a South African university. We focus on one of the courses, Human Communication Development, that comprises the four year programme of study. A firstyear, first semester course that is attended by both SLP and Audiology students, it aims to introduce fundamentals of the communication process and its development at a pre-clinical level. We aim to show how theoretical principles from higher education can be implemented at a micro level in a course of the SLPProgramme. The principles of constructive alignment are introduced and exemplified through description of the revision of this course. All academicand clinicalstaffinvolved in the programmecontributed to the development of the course.A template for curriculum revision is presented which allows for the explicit alignment of intended learning outcomes, teaching and learning activities and criterion referenced assessment. Staff participants recorded reflections on theirownlearning in personal reflection logs.Through thisjournaling processparallelsaredrawnbetween the 'teachers' voyage of discovery and that of the students.

\section{Keywords: Constructive alignment, curriculum development, speech-language pathology.}

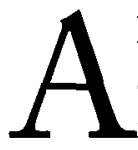
11 speech and language pathologists (SLPs) are involved in education: we work in classrooms with learners and educators; we educate parents and colleagues about speech, language and feeding / swallowing difficulties; we teach clients about various aspects of communication, and educate ourselves and our colleagues in an ongoing way about the content and practice of our profession. Those of us involved directly in educating future SLPs through their university academic and clinical training are also involved in education: although typically our focus as lecturers and clinical educators in SLP programmes will have been on the content of what we teach. Our expertise and interest typically lie in the clinical areas in which we have studied and worked, rather than in the process of adult education itself. Chadwick (2004, p.267), notes in the context of orthodontic specialist training - a different profession but with links to our own - that:

"Traditionally curriculum design is one aspect of education that most of us would not have expected to have any direct involvement in. However, much of the creativity and power in teaching lies in the design of the curriculum. Changes to the curriculum have implications for current and future trainees, teachers on specialist programs and all providers of specialist care."
In the field of SLP there are entire texts that have been dedicated to the subject of professional education of SLPs (e.g. Stengelhofen, 1993; McAllister et al., 1997; Brumfitt, 2004) and papers which focus on SLP curricula both internationally (e.g. Davis \& van der Gaag, 1992; Kamhi, 1995) and in the South African context (e.g. Kritzinger \& Louw, 2003; Khan, 2007). However the amount that has been written about professional education remains extremely small in relation to the large literature on theoretical aspects of communication difficulties. Similarly in medicine, it is only fairly recently that knowledge of medical education has been amassed and the area has become one of interest in its own right.

What are the challenges for SLP curricula?

Along with other professions such as dentistry and medicine, training of SLPs requires professional education: a process different to that of higher education for a theoretical degree. The aim is to produce
Author Contact:
Division of Communication Sciences and Disorders
F45 Old Main Building
Groote Scbuur Hospital
Observatory
7925
Soutb Africa
E-mail: michelle.pascoe@uct.ac.za 
professionals who are not only able to carry out the 'technical' or subject-specific challenges of being an SLP but also have an understanding of ethical aspects of practice, are able to demonstrate flexibility of thinking, problem-solving skills, creativity as well as communication and interpersonal skills that allow the facilitation of change in their clients' lives. Pascoe, Stackhouse and Wells (2006) talk about 'thinking therapists,' i.e. SLPs who are able to evaluate their practice in an ongoing and self-critical way. It is not surprising therefore that although institutions can provide teaching in subject-specific content and even professional methods, the application has to be found within the actual work context. Inevitably many students face difficulties in transferring their theoretical knowledge to clinical settings. The divide between theory (what happens in lectures) and therapy (what happens in clinics) is often perceived by staff and students alike as wide. Whitworth, Franklin and Dodd (2004) describe SLP students in the UK whose clinical practice reflected what they had experienced in clinical placements, irrespective of their theoretical knowledge gleaned in lectures.

In order to be able to practice their profession, students must meet the criteria specified by the profession's regulatory body in whatever country they choose to work. Educators designing curricula need to steer a tricky course between ensuring that these outcomes are met by the end of the programme, but that at the same time the experience of students is a rich and interesting one affording them the opportunity for deep, rather than surface learning. Deep learning has been defined as learning which achieves outcomes because students are engaged with their learning and have no desire to cut corners. They wish to fully understand their subject. In contrast surface learning is where students are not engaged fully with their learning. Their main focus is to pass a course rather than achieve mastery of a subject. Learning does not happen in a long-lasting and effective way (Biggs \& Tang, 2007). Chadwick (2004) writing about orthodontic specialists training in the United Kingdom noted that whether constructive alignment can be achieved in the curriculum ultimately depends on the relationship between these aspects of the educational process and the various bodies responsible for their delivery in the UK. Similarly Toohey (1999) notes that while professional competence standards can be very useful sources for guiding curriculum design their tendency is to focus on the technical performance of specific tasks and roles. If learning outcomes include technical competency these should be balanced by outcomes in knowledge and attitudes that contextualise these skills (Chadwick, 2004).

In addition to the complex task of managing academic and clinical learning, SLP courses face a challenge in that they are typically heavily loaded courses in terms of content (Whitworth et al., 2004). The timetable from most SLP programmes typically leaves little room for self-study or reflection, skills which are increasingly shown to be imperative for deep learning (Gultig, Lubisi, Parker \& Wedekind, 1998; Irving \& Young, 2005). SLP is a profession that draws heavily on the combined knowledge of other disciplines such as psychology, linguistics and biomedical sciences.

\section{The SLP curriculum in South Africa}

In South Africa, there has already been rapid transformation in the education of SLPs since the mid-1990's when training programmes began making changes in line with the new democracy and the urgent need to address previous imbalances in the country's higher education system and to provide equitable service to the underserved majority of the population. Many of the SLP programmes in SA have been aggressively recruiting students who represent the diversity of the SA population. Graduates are urgently needed who will be able to speak languages other than English and Afrikaans (as has traditionally been the case), and who themselves will be able to access the diverse array of cultures in the country. Furthermore, since there are few universities in Africa which train SLPs apart from those in South Africa, there are a great many students from the continent who have languages and cultures beyond those of only this country. Linguistic and cultural diversity is a great asset and the richness of diversity in our classrooms is an exciting asset to be embraced. Nevertheless studying in a language that is not a first language poses challenges. In addition to linguistic diversity students come from a variety of cultural and educational backgrounds. Their experience of language for academic purposes varies widely: some students will arrive at university equipped with basic academic skills such as being proficient in reading academic texts, using glossaries and indexes, writing definitions and carrying out literature searches. Other students will not have been exposed to tasks such as these and will need support to master these basic skills. In a profession in which language is central to the job, linguistic diversity can present complex dilemmas.

As for all SLP graduates, SLPs wanting to work in SA must exit their programmes of study with the necessary knowledge and skill to work independently as stipulated by the Health Professions Council of South Africa (HPCSA, 2003). The situation in South Africa is different to countries such as the UK and USA where SLPs will typically work in settings where formal mentoring and supervision arrangements will be in place to ensure that newly qualified clini-cians continue to develop their skills in a supervised way'. In South Africa, such mentoring and supervision is typically not available: new graduates carry out a year of community service in communities which are often rural and remote, where they may be the only SLP - indeed they may be faced with establishing services where previously none have existed, and educating and advocating for the role of SLP services. Thus it is imperative that graduates are able to practice competently and independently: Not only do we need to produce the 'thinking therapists' already described but we also need to develop agents for change who will be able to bring about broader socio-political changes as they develop and advocate for services for the population of their country.

The training of SLPs in SA has historically been different to education of SLPs in other countries such as the USA and UK, in that training leading to a dual registration in both Speech Pathology and Audiology was until recently offered at each of the training institutions. Now many of the training institutions, including our own, offer separate programmes in Speech Pathology and Audiology since these 
are entirely separate professions. These programmes aim to be responsive to the wider population of South Africa, taking into account the burden of disease profile of the country: HIV / AIDs and TB are prevalent in Southern Africa and require specific services from both SLPs and Audiologists. These aspects have not always been included in training programmes in South Africa and may not receive the same level of emphasis in training programmes elsewhere, which are likely to have their own population-specific issues. Primary Health Care (PHC) is a key philosophical underpinning of health programmes in South Africa, and the training programmes for SLP and Audiology thus aim to include not only training that focuses on rehabilitation, but which also gives emphasis to PHC's continuum of care which includes prevention of communication difficulties, and promotion of communication more generally. Against this backdrop, courses such as 'Human Communication Development' remain common to both Speech-Language Pathology and Audiology programmes which means that the course needs to be designed so that it is appropriate for students studying in both programmes. Separating Speech-Language $\mathrm{Pa}$ thology and Audiology programmes has meant that some unloading of the overloaded curriculum has occurred but the courses remain very high in terms of credit weightings when compared to other similar 4 year programmes (Brumfitt, 2004).

\section{What are the challenges for Higher Education?}

Many of the challenges described in our specific context are not unique: Biggs and Tang (2007) note that around the world, the range of academic ability in university classes is wider than it has ever been: "The brightest and most committed students still go to university, as they have in the past, but they sit alongside students of rather different academic bent." (p.2). These authors note that around the world about $40 \%$ of school leavers now attend university, in contrast to figures; of approximately $15 \%$ ten years ago. In addition to these changing demographics, there is an increasing pressure for universities to offer value for money in their curricula: education is a commodity than can be bought and students yiew themselves as consumers entitled to an appropriate service.

Traditionally those involved in higher education may have regarded teaching as second priority to research, but the increasing pressure on universities to provide a relevant, quality and value-for-money learning experience has meant that universities are now striving to create a more learnerfriendly environment. Many universities around the world now place emphasis on funding of teaching/ learning cen- tres, as well as recognising that research into teaching of one's content area is as important as research into one's content area per se (Gultig et al., 1998; Biggs \& Tang, 2007).

It has been suggested that the solution to the challenges that learners and educators face in higher education is to immerse students in an environment that makes clear the intended outcomes of the learning process, and follows curricula that explicitly encourage this. Constructive alignment has been used to achieve this aim and has been described as an effective yet flexible approach to learning in higher education (Biggs, 1996; Biggs \& Tang, 2007).

\section{What is constructive alignment?}

Constructive alignment is a form of outcomes based education in which intended learning outcomes (ILOs) are clearly defined and drive the rest of the educational process (Biggs, 1996, 1999). There are two parts to constructive alignment:

1. Constructivism: Students construct meaning from what they do in order to learn. They build on the knowledge they already bring to the process. Rather than passive participants who have knowledge transmitted to them, they are active participants in the process (Biggs \& Tang, 2007). Constructivism is a theory of learning that can be seen on a continuum so that there are actually a variety of types of constructivism rather than one unified theory (Doolittle, 1999). These include social constructivism, cognitive constructivism and radical constructivism (see Fosnot, 1996 for further discussion of learning theories). Holmes et al. (2001) have developed a new educational theory - 'communal constructivism' based largely in response to the development of technology and its increasing use in education through ICT applications. Communal constructivism purports to move beyond social constructivism and sees individuals constructing meaning together not just alongside each other but for each other, often through joint development of Information and Communication Technology (ICT) applications.

2. Alignment: The teacher or lecturer aligns the planned learning activities with the learning outcomes. The basic premise is that the curriculum is designed so that the learning activities and assessment tasks are aligned with the ILOs that are intended in the course. A course is constructively aligned when (a) the ILOs are stated clearly, and explicitly communicated to the students; (b) the teaching and learning activities (TLAs) match the ILOs, and (c) the assessment(s) match the ILOs. Figure 1 illustrates these principles of constructive alignment.

Biggs and Tang (2007) describe the process of constructive alignment which can take place at a range of levels: in-

Figure 1. Aligning learning outcomes, learning and teaching activities and the assessment. Adapted from Biggs (1999) p.27

\begin{tabular}{|c|c|c|}
\hline $\begin{array}{c}\text { Leaming and } \\
\text { teaching activities } \\
\text { Designed to meet } \\
\text { learning outcomes }\end{array}$ & $\begin{array}{c}\text { Assessment } \\
\text { methods } \\
\text { Leaming } \\
\text { Outcomes }\end{array}$ \\
\hline $\begin{array}{l}\text { Designed to assess } \\
\text { learning outcomes }\end{array}$
\end{tabular}


dividual courses, programmes and in institutions. This paper describes the constructive alignment process that took place with one course within our SLP programme, but was carried out as a micro part of a larger and ongoing process of constructive alignment for the entire programme. Biggs and Tang (2007) suggest that when considering a single component of a programme, constructive alignment is achieved by carrying out the following steps:

- Defining the intended learning outcomes.

- $\quad$ Selecting learning and teaching activities likely to enable the students to attain the outcomes.

- Assessing the students' outcomes and grading the students learning.

\section{Defining the Intended Learning Outcomes}

There is a large body of literature on the use of learning outcomes in higher education (e.g. D'Andrea, 1999; Biggs \& Tang, 2007). Learning outcomes have been described as the middle ground between over generalized statements of learning (e.g. 'aims') and over-specified statements of learning (e.g. 'objectives') (Chadwick, 2004). ILOs determine the curriculum content, the teaching and learning approaches or activities carried out and the assessment techniques used to evaluate the end result. If students are made aware of ILOs then they are likely to take more responsibility for their own learning. Furthermore, when students focus their attention on assessment tasks (as inevitably happens), they should be able to see the explicit links between the ILOs and the assessment task. The criteria for assessment should only differ from the ILOs by the fact that assessment tasks will necessitate more detail of performance levels required for specific results or grades. The logic underpinning constructive alignment is very simple. Biggs and Tang (2007) use the analogy of a parent who wants their child to learn to dress herself. The ILO in this case would be for the child to be able to dress herself independently; the teaching and learning activity would be for the child to practice dressing herself; and the assessment would be how successful the child is in independently dressing herself.

ILOs are specified by use of verbs: We want students to actively do something, e.g. apply, list, hypothesise etc. In considering the verbs to describe learning outcomes, we can draw on research that has focused on kinds of knowledge and levels of understanding. Biggs (1999) identifies four different types of knowledge:

1. Declarative knowledge: knowing what, or knowing about, in other words the 'content' of knowledge

2. Procedural knowledge: knowing how to do things

3. Conditional knowledge: knowing when to do things

4. Functioning knowledge: knowing how to employ the first three types of knowledge to solve problems and function as an effective professional. Functioning knowledge is built on the other three types of knowledge.

The relationship between the four different types of knowledge is shown in Figure 2.

The distinctions between the different types of knowledge are important as they relate to what the curriculum should be about. If we want our students to demonstrate functioning knowledge then we need to ensure that the curriculum has outcomes which tap into this level. Neverthe-
Figure 2. Relationships between different kinds of knowledge (adapted from Biggs and Collis, 1982)

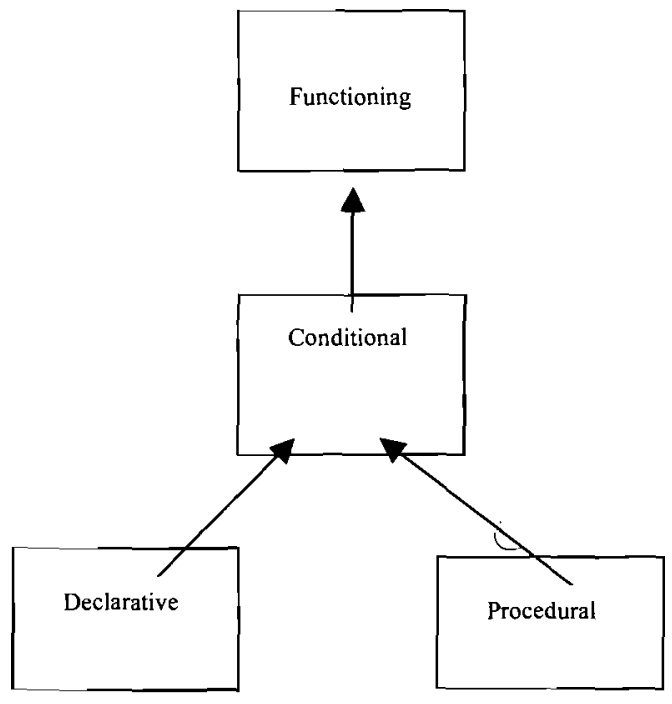

less it is appropriate to mix the levels of learning required, and a developmental progression should be noted. In a first year course it would be expected to have some lower level outcomes that deal with the basic facts, moving towards having higher levels that require the students to deal with new situations.

The SOLO (structure of the observed learning outcome) taxonomy (Biggs \& Collis, 1982) provides a systematic framework for describing how learners' understanding increases in complexity as they master academic tasks. It has also been used to (a) develop ILOs: what is the desired level of a student's understanding at the end of a course?, and (b) evaluate learning outcomes so that we can determine the level at which individual students are actually operating. A visual representation of the SOLO taxonomy is shown in Table 1.

Selecting learning and teaching activities likely to enable the students to attain the outcomes.

There is increasing awareness that traditional lectures are no longer appropriate for effectively meeting the needs of diverse student populations (Biggs \& Tang, 2007; Whitworth et al, 2004). Looking beyond the lecture room there are a wide range of teaching and learning methods suitable for small or larger groups of students. Some of these have been systematically researched and evaluated for effectiveness (see Brown \& Atkins, 1988 for a review).

Problem-based leaming (PBL) is an example of an alternative approach to teaching and learning which has received considerable attention and been the source of some controversy. PBL involves confronting students with problems from practice which provide a stimulus for learning (Boud \& Feletti, 1991). PBL typically occurs in small group, where students are considered to be active participants in their own learning. Facilitators typically select authentic assignments or cases from the discipline. Students are required to locate and evaluate various resources in the field (SavinBaden \&Wilkie, 2004; Tan et al., 2005). To date PBL has been widely implemented in medical curricula (Biggs, 2003) but has shown a more limited spread outside medicine. Its 
Table 1. A summary of the SOLO taxonomy (Biggs $\&$ Collins, 1982) with bierarchy of verbs that can be used to form ILOs

\begin{tabular}{|l|l|}
\hline Level of understanding & Description \\
\hline Prestructural & The learner misses the point \\
\hline Unistructural & $\begin{array}{l}\text { The learner's knowledge is accurate } \\
\text { but concrete and minimalistic }\end{array}$ \\
\hline Multistructural & $\begin{array}{l}\text { The learner understands boundaries } \\
\text { but not of systems; links between } \\
\text { concepts are not made }\end{array}$ \\
\hline Extended abstract & $\begin{array}{l}\text { The learner orchestrates between } \\
\text { fact and theory; action and purpose; } \\
\text { links are made between concepts. }\end{array}$ \\
\hline $\begin{array}{l}\text { The learner is required to } \\
\text { conceptualise at a level beyond what } \\
\text { has actually been taught }\end{array}$ \\
\hline
\end{tabular}

effectiveness is controversial: proponents of PBL claim that learning that occurs through PBL is deep and a greater retention of knowledge occurs (Dolmans \& Schmidt, 1994). Students who were asked to evaluate PBL in an Occupational Therapy curriculum reported benefits in managing information, critical reasoning, communication and teambuilding (Hammel et al, 1999).

Despite some of the advantages associated with PBL, it has been found to be a resource-intensive approach which means that many university programmes simply do not have the budget to adopt PBL in its pure form. Critics of PBL suggest that there is no real difference in the outcomes of PBL versus non-PBL curricula (Colliver, 2000). While students seem to enjoy the approach and may show clinical skills such as problem-solving in advance of their nonPBL peers, the students ultimately lack a solid theoretical foundation and perform more poorly when their theoretical knowledge is assessed (Nandi et al, 2000). Furthermore it seems unlikely that PBL alone would give students sufficient opportunity to develop their clinical skills and attitudes, e.g. the development of interpersonal skills and therapeutic manner is something which needs to be learnt in real-life clinical settings with clients, under supervision (Grundy, 2004).

Given the resource issues associated with implementing full-scale PBL, the debate surrounding its efficacy is academic for many programmes. Whitworth et al. (2004) describe the implementation of case-based problem-solving for SLP students. In this approach some of the principles of PBL were drawn on, but small group problem-solving was just one of the teaching and learning approaches used in combination with a range of other methods. Brainstorming, role-plays, tutorials and workshops are all teaching and learning activities (TLAs) which have been used to good effect.

Assessing the students' outcomes and grading the students learning.

Constructive alignment suggests that consideration needs to be given to how students' learning is assessed, and how a final grade is arrived at. There are two main approaches to assessment: Normreferenced assessment and criterion-ref- erenced assessment. The traditional norm referenced assessment model is where students' 'learning' is assessed by their responses to individual questions with marks assigned to their 'correct' responses. Biggs and Tang (2007) note that this often encourages students to go for a mark 'trawl' in exams, trying to pick-up marks here and there - rather than being motivated to learn because of selfinterest and attempting to understand what it is they have learnt. Norm-referenced assessment is where students are compared to each other: those who use this system will typically end up with a bell-shaped curve with a small group of students who obtain A grades, a larger group obtaining Bs, and the biggest group obtaining $\mathrm{Cs}$, while students with Ds and E's and F's again decrease in number. Biggs and Tang (2007) describe this as 'grading on the curve' (p.166.)

Criterion-referenced assessment is where grades are awarded according to how well students meet the desired learning outcomes. Using this approach, one is required to identify the outcomes that you aim to develop - and to what extent - as part of the unit planning and documentation. This becomes sound evidence for students that they have indeed developed in some way these particular attributes. Table 2 shows an example of a generic criterion-referenced grading system.

Nearly all degree programmes will require the criteria grades to be converted to a grade: this is fairly straightforward; a good 'A' gets $85 \%$, a bare 'A' gets $75 \%$, and so on. For a more in-depth discussion of assessment, see Biggs (1999, Chapters 8 and 9).

Formative assessment is assessment that affords students the opportunity to gauge how well they are meeting ILOs. They may receive marks but these do not count towards their final grades for the course. Formative assessment is part of the instructional process. When incorporated into classroom practice, it provides the information needed to adjust teaching and learning while they are happening. In this sense, formative assessment informs both teachers and Table 2. Example of a generic criterion-referenced grading system

\begin{tabular}{l} 
Grading Criteria \\
Grades will depend on how well you can demonstrate that you have met all \\
ILOs: \\
$\begin{array}{l}\text { A: Awarded if you have clearly met all the objectives, displaying deep } \\
\text { knowledge of the content, creative / original thinking, applying the concepts } \\
\text { effectively to new situations }\end{array}$ \\
\hline B: Awarded when all objectives have been met well and effectively \\
$\begin{array}{l}\text { C: Awarded when the objectives have been addressed satisfactorily, or where } \\
\text { evidence is strong for some objectives, but weaker in others. }\end{array}$ \\
F: Less than C, or work not submitted \\
\hline (adapted from Biggs, 2003)
\end{tabular}

(adapted from Biggs, 2003) 
students about student understanding at a point when timely adjustments can be made. Summative assessment also affords students the opportunity to gauge how well they have met ILOs but these marks are used towards final grades. In a balanced and transparent assessment system, both summative and formative assessments are an integral part of information gathering.

Constructive alignment was developed in order to promote quality learning at university (Biggs, 1996, 1999) and to address some of the challenges associated with higher education outlined in the previous section. Proponents of constructive alignment aim to move students away from surface learning toward deep learning. Rather than having students 'cramming' for examinations but not being able to remember and truly understand what is learnt in the longer term, constructive alignment aims to promote active learning where students take responsibility for their own learning and leave university as life-long learners equipped with the necessary skills and motivation to continue to develop their learning in the workplace. These are important aims for SLP educators (Whitworth et al., 2004; Penn, 2007). This study aims to describe how principles of constructive alignment were applied to a first year course in our SLP programme (Human Communication Development), a key foundation for both SLP and Audiology programmes.

\section{Method}

\section{Aim}

The main aim of this paper is to describe the curriculum revision process that took place with one SLP course based on the principles of constructive alignment. More specifically the study aimed to describe the intended learning outcomes (ILOs); teaching and learning activities (TLAs) and assessment that have been devised for this course, and to present a template which can be used for mapping these.

\section{Design and overview}

This study was carried out following principles of participatory action research which focused on one specific course within an SLP programme that is treated as a self-contained case. Participatory action research focuses on the effects of researchers' actions within a community with the goal of improving the performance of the community (Reason \& Bradbury, 2001). A cyclical method of planning, taking action, observing, evaluating and critical reflecting are employed. It is a collaborative method to test new ideas and implement action for change, and for these reasons was appropriate for the ongoing nature of the curriculum revisions within the SLP programme.

Three phases of the study are described in this paper. These phases are:

Phase 1: Preparatory work and review of existing course

Phase 2: Framework and Principles

Phase 3: Documentation

Two remaining phases (implementation and evaluation) are part of the participatory action research cycle that have yet to be carried out.

\section{Participants}

All academic and clinical staff working in the SLP and Audiology programmes participated in the study $(n=13)$. It was considered that although clinical educators are not directly involved in carrying out academic teaching and have no clinical contact with SLP students in first year, they could provide valuable input into the curriculum based on their own experiences as SLP/Audiology students, then as qualified SLP/Audiologists in the workplace and through their clinical teaching experiences with SLP students of later years. First year SLP and Audiology students ( $n=34)$ contributed to Phase 1 of the study.

\section{Procedure}

Phase 1: Preparatory work and review of existing course

SLP staff met for two hours on a weekly basis over the course of one university term. Initial meetings focused on establishment of a contract for the SLP 'curriculum working group', whereby all staff were invited to participate in the curriculum revision process in a collegial atmosphere and with respect for each other's opinions. It was agreed that the curriculum work should reflect the consensus of the group and belonged to the entire staff rather than to one or two individuals. Although course convenors were assigned ultimate responsibility for each course, it was agreed that all would give input and in theory any member of staff should be able to teach the course. A time frame was agreed. Staff carried out readings to develop their knowledge of current practice and research into curriculum design and university teaching / adult education. Discussions of readings took place and staff decided to document their own personal perspectives on this learning process in reflective logs. These reflections were an ongoing part of the research described here, rather than being limited to a specific phase of the study. The course outline for the existing course was discussed and reviewed in the light of readings into curriculum design. The process was documented and placed on the intranet for students of the programme to give input on, as they could not attend the curriculum discussions given their busy schedules.

Anonymous student feedback about the existing course was collected using a written questionnaire. Thirty-four students completed feedback sheets at the end of the course. The questionnaires used a 5 point rating scale to assess aspects of the course related to (a) learners own knowledge that they brought to the course; (b) clarity and explicitness of ILO's of the course; (c) content of the course; (d) the teaching and learning activities used; (e) assessment methods, and ( $f$ ) overall rating of the learning experience and the effect of the course on the student's interest in the subject. In addition space was provided in the written feedback sheet for learners' to add their own comments on any aspects of the course.

\section{Phase 2: Framework and Principles}

In this phase, the staff agreed on a guiding framework and principles that would ensure the new course curriculum was educationally sound and based on a body of theoretical knowledge. In addition to consideration of these theoretical aspects, attention was given to practical aspects such as a template which could be used to capture the discussion of key components of constructive alignment.

Phase 3: Documentation

In the final phase, the specific details of the constructive alignment was documented using the template devised in phase 2 . Results for Phase 2 and 3 are presented separately, but in keeping with the nature of participatory action re- 
search they were closely linked and in reality overlapped to a great extent, e.g. when the template was actually used it was found to be missing key aspects, and this necessitated revision of the template; at various points we reconsidered theoretical underpinnings and continued to read widely throughout.

\section{Results}

Results are presented following the three phases of the study.

Phase 1: Preparatory work and review of existing course

\section{The course}

Human Communication Development (HCD) is a first year, first semester course that all students in the four year SLP and audiology programmes are required to take. The course aims to introduce students to normal processes of human communication and give them an understanding of how communication develops over the life-span. It is a pre-clinical course that forms the foundation of most other courses in the SLP and Audiology programmes. It consists of 48 contact hours and in 2008 was taken by 34 students, from both Speech pathology and Audiology programmes. The course was previously known as "Normal Speech, Language and Hearing Development" but the title was changed to reflect the diversity of communication development versus one 'standard' norm. This thinking fits with the programme's philosophy of inclusiveness of cultural and linguistic diversity of learners in current classes.

Appendix 1 shows the unrevised version of the course aims. Immediately striking about the existing course outline was that there are a great many aims and objectives. Biggs and Tang (2007) suggest that ILO's should not exceed more than about 7 or 8 since greater breadth of coverage typically means that the depth of understanding is compromised. In the existing course outline there were 4 broad aims, and 12 more specific objectives which were grouped into knowledge, skills and attitudes categories. Many of these will remain appropriate but consideration needs to be given to the core knowledge that is essential for students to acquire rather than the knowledge, skills and attitudes that are 'nice to have.' In order for constructive alignment to occur ILOs will need to be specifically stated using appropriate verbs which can then be used to guide the TLAs and assessments. The existing aims had been outlined from the educators', rather than the learners' point of view, e.g. 'To provide a comprehensive working knowledge of normal speech, language and hearing development from birth, through the infant-, toddler-, pre-school and school-age phases.'

The information in Appendix 1 shows the emphasis that previous curriculum revisions have placed on content - rather than on TLAs and assessment. As it stood the course objectives were considered to be broadly appropriate as ILOs: they used verbs which fit with the frameworks outlined in the previous section. Nevertheless these needed to be prioritised, and reviewed so that they linked up explicitly with the teaching and learning activities used to achieve outcomes (not included previously) and assessment (also not detailed previously). No sense was given in this document of the criteria by which students' performance on this course would be judged.

Students evaluated the existing, unrevised course (in which they participated in the first semester of 2008) by anonymously completing a written questionnaire handed to them in the last session of that course. The results will be compared with the results from the new cohort of first year

\section{Table 3. Summary of first year student feedback of existing Human Communication Development course}

\begin{tabular}{|c|c|c|}
\hline Area of evaluation & $\begin{array}{l}\text { Mean rating } \\
\text { (1=unsatisfactory; } \\
\text { 3=average; } \\
\text { 5=excellent) }\end{array}$ & Qualitative comments \\
\hline $\begin{array}{l}\text { A: learners own knowledge that they } \\
\text { brought to the course }\end{array}$ & 3.25 & \\
\hline $\begin{array}{l}\text { B: clarity and explicitness of ILO's of the } \\
\text { course }\end{array}$ & 4.16 & \\
\hline C: Content of the course & 3.91 & $\begin{array}{l}\text { "Very interesting.' } \\
\text { "Stimulating and easy to cope with." } \\
\text { "Unstimulating in terms of content." }\end{array}$ \\
\hline $\mathrm{D}$ : the teaching and learning activities used & 4.25 & $\begin{array}{l}\text { "It would be nice to watch more movies about speech." } \\
\text { "The lecturer should use more methods to attain the students' attention better." } \\
\text { "A touch boring at times... should be more interactive." } \\
\text { "Slides got a bit boring at times." } \\
\text { "More visuals and practicals would help us from getting bored." }\end{array}$ \\
\hline E: Assessment methods and feedback & 3.8 & $\begin{array}{l}\text { "I didn't feel I could adequately judge my progress." } \\
\text { "Have more tests so we can judge our progress better." } \\
\text { "Have spot tests and more practise throughout the course." } \\
\text { "Mark tests more strictly so that we know the "perfect answer." } \\
\text { "I loved the project on child development: creative activities are fun and help } \\
\text { learning." }\end{array}$ \\
\hline $\begin{array}{l}\text { F: overall rating of the learning experience } \\
\text { and the effect of the course on the } \\
\text { student's interest in the subject }\end{array}$ & 4.12 & $\begin{array}{l}\text { "It has given me a broad base to build on." } \\
\text { "On the whole has gone well but I find it hard to keep up with reading." }\end{array}$ \\
\hline
\end{tabular}


students who will experience the revised course in the first semester of 2009. Results from key questions of the student evaluation feedback are presented in Table 3.

Table 3 shows that while the overall rating given by students was good; the areas around which most critical feedback was obtained was in the area of teaching and learning activities, and assessment. In terms of TLAs many students noted that they would have preferred more interaction, rather than the lecture-based format which was primarily employed. In terms of assessment it was interesting to note that several students asked for many assessments so that they could develop a greater sense of how their learning was progressing. Some of the qualitative comments provided support for the use of a practical assignment. All in all the course received a positive evaluation, but there is certainly room to improve each of the aspects outlined in Table 3 and most specifically the TLAs and assessments.

At this point in staff participants' learning journey there was a general sense of excitement and of the importance of transforming the curriculum, however uncertainty about the outcome of the process was also high - as illustrated by excerpts from staff reflective logs below:

Participant 1: "Reading a wide-range of papers on teaching and learning was fascinating. I never knew that this whole body of literature existed - despite my job as a lecturer and being involved in education in schools [as an SLP]. However, I'm not sure how this knowledge will be applied to our curriculum and what we are actually hoping to achieve?"

Participant 2: "I know that there are problems with the course but I'm not sure how we intend to tackle these and whether sessions like this are the best way of using precious time."

Participant 3: "The discussion about the most relevant taxonomy felt like it might be theoretically interesting but it felt divorced from the real problems with the curriculum. I felt overwhelmed and unsure about the contributions I could make. I feel like a 'back-row' girl. This really isn't my area of expertise."

Participant 4: "We have decided to document the [curriculum review] process as a research project. It's immediately made me view my teaching colleagues as research collaborators too - and made the team feel stronger. We started discussing the rationale for what we were doing, aims and methods and it felt exciting to be all pooling our ideas and moving forward, planning future sessions etc. I am still not entirely sure about what the outcome will be - but I feel more accepting of this now because that is what research is all about."

Phase 1: Summary

At the end of this Phase it was concluded that the course has many strengths as it stands: the content is appropriate for the level of the programme and is broadly aligned with the ILOs of the programme. However, aims and objectives need to be reconsidered so that a smaller and more focused set of ILOs are chosen. These then need to be used to guide the TLAs and assessment. Criterion referenced guidelines for students taking this course need to be developed. Feedback from students suggests that the course is currently working well but that students have specific criticisms re- lated mainly to the TLAs used and the assessments.

\section{Phase 2: Framework and Principles}

Constructive alignment was the overriding principle used to guide the curriculum review process. It was agreed that for each course the following process should be followed:

A. ILOs: List a small set of ILOs. These should capture the core outcomes that are required for students to achieve by the end of each course. Each ILO will require an appropriate verb since we want the emphasis to be on what the students can do by the end of the course (See Table 1). Each ILO can be broken down further into the type (See Figure 2) and level of knowledge (Table 1) that is required. Where appropriate, skills and attitudes that will be required to achieve the ILO should be explicitly stated to ensure that a progression of learning takes place.

B. Content: Outline the content of the course by topic area, including a specification of the depth of each topic to be covered ranging from minimal depth $\left(^{*}\right)$ to moderate depth $\left({ }^{* *}\right)$ to most in-depth $\left({ }^{* *}\right)$. Content should be pared down to what is essential to know, rather than what is 'nice to know' following principles of curriculum unloading (Biggs \& Tang, 2007).

C. TLAs: Describe TLAs. These should link explicitly with ILOs, thus for example if students are required to apply knowledge of normal communication to specific cases (an ILO), then they should be given opportunity to do so in TLAs, e.g. either through case-based learning or through visits to appropriate clinical / educational sites. Since it is known that lectures are no longer appropriate as the only TLA, a wide range of more innovative and effective TLAs should be considered.

D. Assessment: Describe assessment. Both formative and summative assessments should be included for each course. Assessments should be explicitly aligned with ILOs and TLAs. In some cases assessments will be the same as TLAs - and this is when alignment is perfect and should not be regarded as a problem (Biggs \& Tang, 2007). Linked to the assessment tasks is the need for each course to contain a criterion referenced guideline where students' performances are described in terms of attributes (e.g. see Table 2 for a generic example). These criteria can be used in assessing students' performance in both formative and summative assessment tasks; as well as helping students to be explicitly aware of where they are currently at in their learning, and what they will need to achieve in order to progress to another grade level.

E. Philosophical underpinnings. Ensure that the philosophical underpinnings of the programme are reflected appropriately in each specific course. Alignment can take place at a range of levels. One way in which we aim to ensure that each specific course meets the needs of the context and is relevant to the broader programme and institutional agenda is by explicitly considering key themes or philosophical underpinnings of the programmes. In our programme these include:
a. Primary health care and contextual relevance
b. Disability and burden of disease
c. Ethics and human rights
d. Biopsychosocial models of health
e. Developing agents for change 
f. Equity and affirmation of diversity.

Each of these aspects should be included where possible in relevant sections of the courses under discussion. A checklist at the end of the template reminds participants to consider whether key themes have emerged in the curriculum outline, and where necessary these can be more explicitly included.

Staff participants showed a mixed range of feelings at this point in the process: some were overwhelmed and apprehensive about the amount of work that needed to be done and the amount of time that it would take. Others were excited about the progress that had been made and the innovations that could be implemented. Specific examples include:

Participant 7: "Wow! I've always thought that the first years of training are just about theory, and as a clinical educator I didn't think I'd have much to offer. But now I'm realising how we have to think ahead to the clinical practice years, and I think we really can make a difference in filling the gap between classroom and on-site learning."

Participant 2: "I'm so excited... almost euphoric at this realisation that as long as we follow guidelines from the theory we can facilitate learning in whatever innovative ways we choose..."

Participant 9: "I have always felt bad, like a bit of a shirker if I don't lecture classes for the full 2 hours. But through this project I am realising that this is absolutely fine - desirable even - especially as we know ILOs can be met through other more exciting ways."

Participant 12: "It's just all come together. I think we are all understanding what it's all about! And actually to take that a step further and understand more about the learning process and the challenges that our students go through... it's been the same for us."

Phase 2: Summary,

At the end of this phase, staff participants had arrived at a template which could be used to capture all the necessary elements for constructive alignment at the level of individual courses. The blank template is included in Appendix 2.

\section{Phase 3: Documentation}

Revision of the existing course following principles of constructive alignment has meant that the new course has ILOs that are closely aligned with TLAs and assessment. Table 4 shows the newly-aligned HCD course which Speech-Language Pathology and Audiology students will take in the first semester 2009. The layout of the table helps to make the alignment visually explicit.

\section{Column A: ILOs}

The first column of Table 4 delineates the ILOs which were selected for this specific course. This column is undoubtedly the most important of the table: the cornerstone on which the remainder of the table depends. This importance was reflected in the large amount of discussion and debate that was generated among staff participants for each ILO. Each of the six ILOs for this specific course is accompanied by an explicit statement about the level and type of knowledge required based on the theoretical frameworks summarised in Table 1 and Figure 2.

Six ILOs were selected to capture the core outcomes of the course. This smaller number was in contrast to the larger number of aims / objectives stated in the previous version of the course (Appendix 1). Through the careful selection of these ILOs, the course has been 'unloaded.' It is our belief that this will encourage deep learning of essential information that students will be able to retain and build on in future courses, rather than surface learning of a large number of facts which most students will forget shortly after the final examination. The focus has shifted from breadth to depth as suggested by Biggs and Tang (2007). The verbs included in our ILOs for this course are limited only to 'list' (e.g. ILO4: "List principles of normal develoment') and 'describe' (e.g. ILO3: 'Describe anatomy and physiology of the auditory system and speech mechanism.') and thus are reflective of declarative knowledge (knowing 'what') at the multistructural level. It was felt that these low level verbs are appropriate for a first year, first semester course, and in our planning of courses that follow this one the developmental progression to higher levels of knowledge is seen.

ILO1 ('Describe the scope of practice of Speech-language pathology and Audiology professions') may seem an unusual choice of outcome for a course in typical development of communication. However, given the overall aims of the programme: to produce competent professionals who meet the exit level criteria of the HPCSA, staff participants considered it important to explicitly and upfront expose first year students to issues surrounding scope of practice. This course is an obvious place to do so. ILOs typically focus on knowledge, which is clearly a key component of our template. However it was felt that skills and attitudes should also be explicitly stated in our template as linked to each outcome. Table 4 shows common threads in both of these areas: staff participants felt strongly that skills possessed by 'thinking therapists' such as the ability to critically self-reflect (see ILOs 1 and 4), work well in groups (see ILOs 2 and 3), and be respectful and accepting towards diversity of all kinds (see ILOs 4, 5, and 6) are skills which should be encouraged from the earliest part of the curriculum, and not only in the clinical practicum of the programme. ILO3 'Describe anatomy and physiology of the auditory system and speech mechanism' has been included as SLP students will no longer take an in depth 12-week course on anatomy and physiology of the ear, hence further unloading.

\section{Column B: Content}

Column B focused on content areas that will need to be covered in the course, and is analogous to a course outline in more traditionally formatted student handouts. Since previous curriculum work had focused primarily on content, the content of the course did not differ substantially to that of the original course (as shown in Appendix 1). One of the changes in the area of content links to ILO 1: the overview of the professions. However, one of the advantages of constructive alignment is that once the issue of what students should achieve by the end of the course has been addressed (i.e. ILOs formulated) the content leads on from here in a fairly straightforward way. The major challenge associated with selection of content is that one cannot include everything on a given topic! Authors such as Irving and Potts (2004), and Biggs and Tang (2007) note that dominance of content limits the aims of teaching and reduces development of skills. 
Table 4. The Revised Human Communication Development Course showing alignment of ILOs, TLAs and Assessment

\begin{tabular}{|c|c|c|c|}
\hline $\begin{array}{l}\text { A. Intended Learning Outcome } \\
\text { (ILO) }\end{array}$ & $\begin{array}{l}\text { B. Content } \\
\text { "Minimal depth } \\
\text { "Moderate depth } \\
{ }^{* *} \text { Most in-depth topic }\end{array}$ & $\begin{array}{l}\text { C. Teaching and Learning } \\
\text { Activities }\end{array}$ & D. Assessment, \\
\hline $\begin{array}{l}\text { ILO1 } \\
\text { Knowledge: Describe the scope of } \\
\text { practice of Speech-language } \\
\text { pathology and Audiology } \\
\text { professions. } \\
\text { - Level: Multistructural } \\
\text { - Type: Declarative } \\
\text { Skills: Ability to reflect on own } \\
\text { communication } \\
\text { Attitudes: Appreciation of the } \\
\text { scope and boundaries of each } \\
\text { profession; willingness to make } \\
\text { links with those in other health } \\
\text { related courses. }\end{array}$ & $\begin{array}{l}\text { "* What is a Speech-language } \\
\text { pathologist? } \\
\text { "What is an audiologist? } \\
\text { "*Terminology such as } \\
\text { communication, speech, language, } \\
\text { disability, hearing impairment and } \\
\text { deafness }\end{array}$ & $\begin{array}{l}\text { Lecture (introductory) } \\
\text { Self-directed study } \\
\text { - Internet search for } \\
\text { information relating to the } \\
\text { professions of SLP } \\
\text { Audiology in South Africa } \\
\text { and one other country. } \\
\text { - Creation of own glossary } \\
\text { of terms }\end{array}$ & $\begin{array}{l}\text { Formative: Spoken explanation to } \\
\text { first year students on another } \\
\text { course (e.g. Occupational } \\
\text { Therapy, Physiotherapy or } \\
\text { medicine) about what is meant by } \\
\text { SLP or audiology. Together } \\
\text { students fill out a worksheet which } \\
\text { encourages self-reflection. }\end{array}$ \\
\hline $\begin{array}{l}\text { ILO2 } \\
\text { Knowledge: Describe the } \\
\text { communication chain, and list } \\
\text { difficulties which might occur when } \\
\text { breakdown happens at different } \\
\text { points in the chain. } \\
\text { - Level: Multistructural } \\
\text { - Type: Declarative } \\
\text { Skills: Ability to solve problems; } \\
\text { and develop logical thinking. } \\
\text { Attitudes: Develop an appreciation } \\
\text { for benefits of working in a group }\end{array}$ & $\begin{array}{l}\text { " The communication chain } \\
\text { * Breakdown in the communication } \\
\text { chain and difficulties that may } \\
\text { occur. }\end{array}$ & $\begin{array}{l}\text { Lecture (introductory) } \\
\text { Peer-learning } \\
\text { - small group discussion of } \\
\text { communication chain and } \\
\text { areas of breakdown } \\
\text { - Problem-solving } \\
\text { worksheet where groups } \\
\text { of students are required to } \\
\text { map specific } \\
\text { communication difficulties } \\
\text { onto the communication } \\
\text { chain. }\end{array}$ & Formative: Class quiz \\
\hline $\begin{array}{l}\text { ILO3 } \\
\text { Knowledge: Describe anatomy } \\
\text { and physiology of the auditory } \\
\text { system and speech mechanism. } \\
\qquad \text { - Level: Multistructural } \\
\text { - Type: Declarative } \\
\text { Skills: Ability to solve problems; } \\
\text { and develop logical thinking. } \\
\text { Attitudes: Develop an appreciation } \\
\text { for benefits of working a group }\end{array}$ & $\begin{array}{l}\text { *Anatomy and physiology of } \\
\text { hearing and balance } \\
\text { "Effects of hearing loss } \\
\text { "Most common pathologies. } \\
\text { "Five physiological processes } \\
\text { needed for speech production } \\
\text { (respiration, resonance, phonation, } \\
\text { prosody and articulation) together } \\
\text { with key anatomical structures } \\
\text { "Effects of difficulties with the } \\
\text { above processes } \\
\text { "Common speech I language } \\
\text { difficulties. }\end{array}$ & $\begin{array}{l}\text { Lectures } \\
\text { Self-directed study } \\
\text { - Intranet worksheets } \\
\text { - Adding of new terminology } \\
\text { to glossary } \\
\text { Peer-learning } \\
\text { - Problem solving } \\
\text { worksheet where small } \\
\text { groups of students are } \\
\text { required to discuss and } \\
\text { make links between given } \\
\text { symptoms and possible } \\
\text { causes. }\end{array}$ & $\left\{\begin{array}{lr}\text { Formative: } & \text { Intranet } \\
\text { and } \quad \text { quiz; } & \text { class } \\
\text { presentations/plenary } & \text { from } \\
\text { problem solving activities } & \end{array}\right.$ \\
\hline
\end{tabular}


TOWARDS CONSTRUCTIVE ALIGNMENT IN THE SLP CURRICULUM

\begin{tabular}{|c|c|c|c|}
\hline $\begin{array}{l}\text { ILO4 } \\
\text { Knowledge: List principles of } \\
\text { normal development. } \\
\text { - Level: Multistructural } \\
\text { Skills: Engagement with young } \\
\text { children; Ability to carry out critical } \\
\text { / structured observation; make } \\
\text { links between observations and } \\
\text { literature; self-reflection skills. } \\
\text { Attitudes: Respect and } \\
\text { appreciation of diversity in peer } \\
\text { and clients; professional } \\
\text { behaviour. }\end{array}$ & $\begin{array}{l}\text { "Developmental patterns } \\
\text { "Developmental predictability } \\
\text { "Developmental milestones } \\
\text { "Developmental opportunities } \\
\text { "Developmental phases } \\
\text { "Individual differences } \\
\text { multicultural issues }\end{array}$ & $\begin{array}{l}\text { Lecture (Introductory) } \\
\text { Self-directed learning: } \\
\text { - Reflection task: Students } \\
\text { contact a relative who } \\
\text { knew them when they } \\
\text { were younger and share } \\
\text { information on their own } \\
\text { early language learning } \\
\text { and achievement of } \\
\text { developmental milestones. } \\
\text { Feedback to small groups } \\
\text { in class. } \\
\text { Experiential learning: } \\
\text { Students spend } 2 \text { hours in } \\
\text { a local creche carrying out } \\
\text { semi-structured } \\
\text { observations of young } \\
\text { children. Students work in } \\
\text { pairs, unless this is not } \\
\text { practical for the setting } \\
\text { (room too small; child } \\
\text { overwhelmed etc.) in } \\
\text { which case they should } \\
\text { work individually but still } \\
\text { have a partner with whom } \\
\text { they share observations. }\end{array}$ & \begin{tabular}{|l} 
Formative: \\
- Small group discussions \\
where a pair of students \\
discuss their observations \\
with another pair. \\
- Individual self reflection \\
worksheet based on \\
crèche observations \\
experience
\end{tabular} \\
\hline $\begin{array}{l}\text { ILO5 } \\
\text { Knowledge: List main categories } \\
\text { of development, and be able to } \\
\text { identify behaviours that fall within } \\
\text { each area and key milestones. } \\
\text { - Level: Multistructural } \\
\text { - Type: Declarative } \\
\text { Skills: Engagement with young } \\
\text { children; Ability to carry out critical } \\
\text { Istructured observation; make } \\
\text { links between observations and } \\
\text { literature; development of writing } \\
\text { and presentation skills; referencing } \\
\text { of appropriate sources of } \\
\text { information } \\
\text { Attitudes: Respect and } \\
\text { appreciation of diversity in } \\
\text { children; professionalism; } \\
\text { empowered to use literature for } \\
\text { problem-solving and become life- } \\
\text { long learners; they can be agents } \\
\text { of change by educating parents } \\
\text { and promoting communication } \\
\text { development. }\end{array}$ & $\begin{array}{l}\text { "Motor development: Gross and } \\
\text { Fine } \\
\text { "Cognitive development and play } \\
\text { "Social-emotional development } \\
\text { "Communication development } \\
\text { including speech, language and } \\
\text { auditory development } \\
\text { "A framework for describing } \\
\text { language development: Form, } \\
\text { Content and Use }\end{array}$ & $\begin{array}{l}\text { Lecture (introductory) } \\
\text { Experiential learning: } \\
\text { Students spend a further } 2 \\
\text { hours in a local crèche (as } \\
\text { above) carrying out further } \\
\text { semi-structured } \\
\text { observations. } \\
\text { Peer-learning: } \\
\text { - Students are grouped } \\
\text { according to the ages of } \\
\text { children they observed. } \\
\text { These small groups pool } \\
\text { their findings and give an } \\
\text { oral presentation based on } \\
\text { creche observations. } \\
\text { Communal constructivism: } \\
\text { Material developrnent for } \\
\text { prevention of } \\
\text { communication difficulties } \\
\text { I promotion of } \\
\text { communication skills (i.e. } \\
\text { pamphlets, posters) } \\
\text { together with short essay } \\
\text { on rationale for selection } \\
\text { and use in specific } \\
\text { contexts which can be }\end{array}$ & \begin{tabular}{|l} 
- Pormative: \\
on creeche observations; \\
different student groups to \\
focus on different age \\
groups) \\
Summative: \\
- Material development (i.e. \\
pamphlets, posters) \\
together with short essay \\
on rationale for selection \\
and use in specific \\
contexts
\end{tabular} \\
\hline
\end{tabular}




\begin{tabular}{|c|c|c|c|}
\hline & & $\begin{array}{l}\text { stored in a file in clinical } \\
\text { resources room and } \\
\text { accessed by all students } \\
\text { and staff for use with } \\
\text { clients / parents. }\end{array}$ & \\
\hline $\begin{array}{l}\text { ILO6 } \\
\text { Knowledge: Describe key aspects } \\
\text { of communication development in } \\
\text { children aged 0-3 years; } 3-6 \text { years } \\
\text { and 6+ years. } \\
\text { - Level: Multistructural } \\
\text { - Type: Declarative } \\
\text { Skills: Engagement with young } \\
\text { children; Ability to carry out critical } \\
\text { / structured observation; make } \\
\text { links between observations and } \\
\text { literature; development of writing } \\
\text { and presentation skills; referencing } \\
\text { of appropriate sources of } \\
\text { information } \\
\text { Attitudes: Respect and } \\
\text { appreciation of diversity in } \\
\text { children; awareness of influence of } \\
\text { contextual factors, e.g. culture; } \\
\text { professionalism; empowered to } \\
\text { use literature for problem-solving } \\
\text { and become life-long learners. }\end{array}$ & 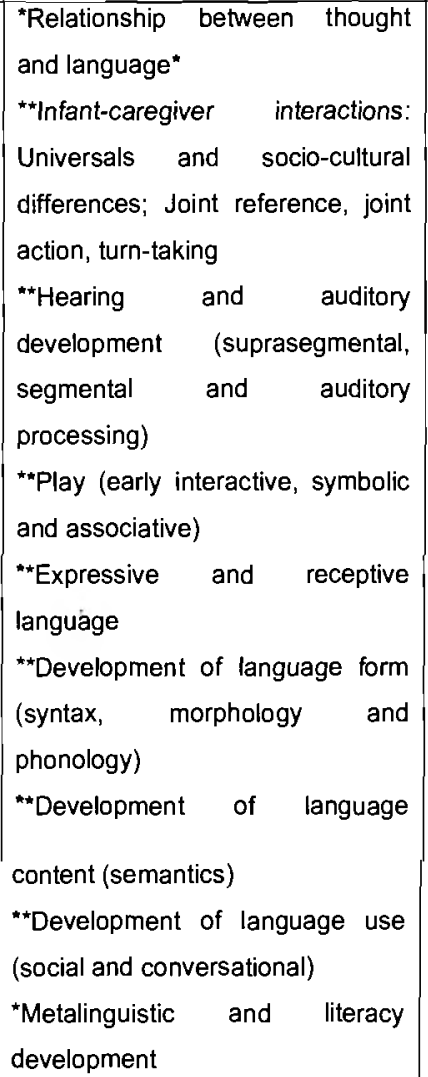 & $\begin{array}{l}\text { Lecture (Introductory) } \\
\text { Video: Depicting and discussing } \\
\text { aspects of typical language } \\
\text { development. } \\
\text { Experiential learning: } \\
\text { Students spend a further } 2 \\
\text { hours in a local creche (as } \\
\text { above) carrying out further } \\
\text { semi-structured } \\
\text { observations. } \\
\text { Peer learning: } \\
\text { Students are grouped } \\
\text { according to the ages of } \\
\text { children they observed. } \\
\text { These small groups pool } \\
\text { their findings and give an } \\
\text { oral presentation based on } \\
\text { creche observations. } \\
\text { Communal constructivism: } \\
\text { As above }\end{array}$ & $\begin{array}{l}\text { Formative: } \\
\text { - Peer presentation based } \\
\text { on créche observations; } \\
\text { different student groups to } \\
\text { focus on different age } \\
\text { groups) } \\
\text { Summative: } \\
\text { Material development (i.e. } \\
\text { pamphlets, posters) } \\
\text { together with short essay } \\
\text { on rationale for selection } \\
\text { and use in specific } \\
\text { contexts } \\
\text { Submission of a reflective } \\
\text { log outlining individual } \\
\text { experience of creche } \\
\text { visits. }\end{array}$ \\
\hline $\begin{array}{l}\text { CHECKLIST: Themes underpir } \\
\text { 1. Primary Health Care and } \\
\text { relevance } \\
\text { 2. Disability and burden of } \\
\text { 3. Ethics and human rights } \\
\text { 4. Biopsychosocial models } \\
\text { 5. Developing agents for ch } \\
\text { 6. Equity and affirmation of }\end{array}$ & $\begin{array}{ll}\text { contextual } & \\
\text { isease } & \text { ILO1 (C); ILO5 (C } \\
& \text { ILO2; ILO3 (B) } \\
\text { f health } & \text { ILO6 } \\
\text { inge } & \text { ILO 4 } \\
\text { iversity } & \text { ILO1 (D); ILO5 (C, } \\
\end{array}$ & $\begin{array}{l}\text { Dded in } \\
\text { D); ILO6 (C;D) } \\
\text { D); ILO6 (C;D) } \\
\text {; ILO6 }\end{array}$ & \\
\hline
\end{tabular}

One way in which we tried to manage the volume of content in this course (and others) is by using a system for grading the depth to which a specific topic should be covered. Thus for example, ILO4 ('List principles of normal development') includes a fairly large number of key topics, but these are content areas that have been graded as minimal depth $\left(^{*}\right)$ and are thus considered important enough to be included, but relatively unimportant in relation to topic areas marked with two $\left(^{* *}\right)$ or three ${ }^{(* *)}$ stars.

\section{Column C: TLAs}

Having selected ILOs appropriate for the course, TLAs are normally relatively easy to select since they should speak directly to what it is that we want students to be able to do by the end of the course. It is acknowledged that lectures are no longer sufficient and appropriate for the type of learning that is needed at university (Biggs \& Tang, 2007; Brumfitt, 2004; Whitworth et al, 2004). Through this curriculum revision process staff have become creative and more flexible about the alternatives to traditional lectures. Neverthe- less Table 4 shows how for all of the six ILOs some traditional lectures have been included. For ILOs 1,2,4,5 and 6 these will take the form of introductory or 'scene setting' lectures which may last from a 15 minute talk to 45 minutes. For ILO 3 'Describe anatomy and physiology of the auditory system and speech mechanism' more lectures will take place. The inclusion of lectures as TLAs in this revised course may to some extent reflect the difficulty that lecturers, used to teaching largely in this way (and most likely having been taught themselves predominantly through this' TLA), feel when having to abandon this method of teaching. Indeed the title 'lecturer' says it all! Another reason for maintaining some lectures in the revised curriculum is that many of the other TLAs carry associated costs which are high in terms of budget and time: experiential learning outside of the university is undoubtedly valuable but needs to be balanced with other more cost-effective and practical means of teaching / learning.

In addition to traditional lectures, the TLAs for the HCD 
course are grouped into 4 main categories: (1) self-directed study, (2) peer-based learning, (3) experiential learning, and (4) communal constructivism. Self-directed study activities encourage learners to engage with novel concepts in active ways which make students more likely to use and 'own' the associated language, than if only passively hearing the language in lectures. Our planned self-directed study activities include intranet and internet research, and the development of a glossary of key terms which can be built on throughout the 4 years of study. Peer-based learning involves students working together and learning from each other. Specific activities involving peer learning in this course include small group discussions on specific topics (e.g. see ILO2); completion of problem solving exercises (see ILOs 2,3) and group presentations (see ILOs 5, 6). Experiential learning occurs where students learn 'on the job' and this has typically occurred in later years of the SLP programme. However, bearing in mind the ultimate outcomes of the programme, and frequent complaints from clinical educators that students do not know what to expect from, for example, a typically developing three-year old, it was considered important for students to have contact with children from as early as possible in the course. Note that the outcomes around the experiential learning activities in the local crèche not only include acquisition of knowledge about how typically children develop and behave, but also skills aspects such as learning to present oneself in an appropriate professional manner. In the HCD course students will spend a total of 6 hours in the local crèche and much of the TLAs and assessment centre around this. Students will be given specific time slots, previously used for lectures, to visit the crèche. Our final TLA is that of communal constructivism where students are given the opportunity to create materials that can be used in their own future clinical years to prevent communication difficulties and promote normal communication development. These materials will be housed in the departmental resource library where they can be freely accessed by students of all years, and it is envisaged that future years of students will contribute and develop them further. This is an example of how students are to be tasked not only with constructing their own knowledge but also with creating tangible academic materials with and for each other. This assignment is a modified version of the assignment that was carried out in the unrevised version of the course, and which students appeared to find useful and engaging as exemplified by the student comment in Table 3: "...creative activities are fun and help learning."

\section{Column D: Assessment}

The final column of Table 4 focuses on assessment of ILOs. These are divided into formative and summative, and is an aspect of the course in which major changes were made. In the unrevised version of the HCD course there were few if any formative assessments carried out, leading students to make the following comments:

"I didn't feel I could adequately judge my progress."

"Have more tests so we can judge our progress better."
"Have spot tests and more practise throughout the course."

(from Table 3).

The revised course now includes several formative assessments taking a variety of formats which include both individual and group work, e.g. ILO1 is assessed by asking students to complete and submit a self-reflective worksheet; ILO2 is assessed though a short written quiz taken in the first 10 minutes of the sessions; ILO5 is assessed through peer presentations in which small groups will share findings with the class. We envisage giving the presenting students qualitative and quantitative feedback from both the course lecturer and the student audience. Summative assessment centres around the communal constructivism task where students are required to develop materials for prevention / promotion purposes. It will be noted that this assessment is identical to the TLA, something which Biggs and Tang (2007) suggest should not be viewed as a problem but rather an example of good alignment: recall the example of the child learning to dress herself where the TLA is dressing herself and the assessment is how well she dresses herself. The materials development is divided into two components: firstly students will receive a group mark for the materials that they develop as a team; secondly they receive an individual mark for their own written essay that explains rationale and thinking beyond the development of the materials. The final summative assessment is submission of a reflective $\log$ outlining the individual experience of the crèche visits. In the unrevised version of the course, final assessment involved a two hour written exam which included a range of multiple choice / true-false and short answer questions covering a broad range of information in minimal depth.

In Table 4 it can be seen that there is an overlap between assessments and ILOs. Each ILO needs to be assessed, but it does not mean that each ILO needs to have its own unique assessment. For example, one assessment task may measure the level of attainment of a number of related learning outcomes as shown in Figure 3 below which maps the links between ILOs and summative assessment tasks.

Our assessment criteria for each of the assessment tasks in this course follows a criterion based approach where students are not graded 'against a curve' or assigned marks for each fact that they remember, but rather are assessed in terms of a set of graduate attributes. These are shown in Table 5 .
Figure 3. Relationship between ILOs and Summative Assessment tasks Learning outcomes

Summative Assessment

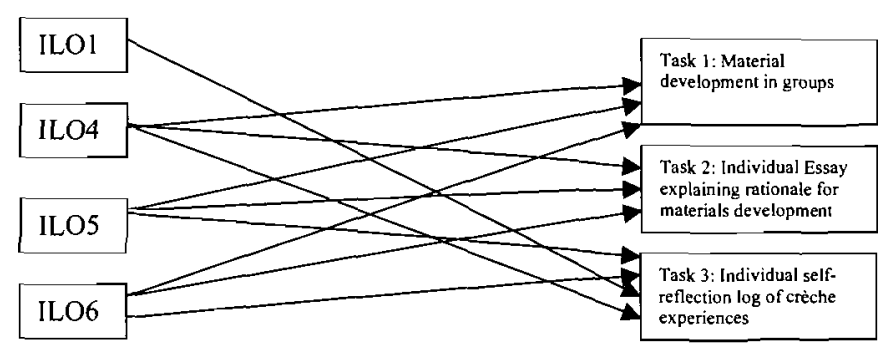




\section{Checklist of key themes}

The final component of Table 4 is consideration of the key themes or underlying philosophy of our SLP programme. Here it can be seen that each of the key themes has come through at some point in the revised curriculum for the HCD course. The themes are addressed to varying depths and revisited over the entire curriculum, e.g. Theme 3: Ethics and Human Rights will emerge more clearly, in for example, the Early Intervention course that follows this course in the second semester. The checklist is included to remind us of the key themes; ensure that at least of some of them are covered and enable us to determine at a glance which have been covered and which will need to come through strongly at other points in the curriculum.

Staff participants shared a range of mixed feelings about the curriculum revision process at this point. On the one hand there was a great sense of accomplishment, exemplified by comments such as:

Participant 2: "We have done so well. What a good team! I am really pleased and impressed at how everyone has contributed."

Participant 8: "I feel really pleased. It was harder than I thought it would be and I feel my brain has had a good workout. It has been great working on this together and it shows how our collective brains are better than one!"

At the same time participants were realistic about the great amount of time and work that had been demanded of them, and the fact that there was a great deal more work to follow:

Participant 10: "It has been great and I think we all feel a strong sense of accomplishment. I do feel sad and a bit sorry for all my previous student groups... they didn't have the benefit of these new teaching / learning experiences."

Participant 11: "It's been amazing. I am proud to have been part of the team and that we worked together so well. It is a lot of hard work...and it isn't finished yet."

Phase 3 Summary

In this phase of the study staff participants used the template developed in Phase 2 to redesign the ILOs, TLAs and assessment for the HCD course. The course was unloaded in terms of content, and ILOs reduced to six clear statements linked to theoretical models of learning, and with requisite knowledge, skills and attitudes described. In addition it contributed to the unloading of the SLP curriculum as inclusion of ILO3 'Describe anatomy and physiology of the auditory system and speech mechanism' permitted one 12 week course to be removed. New TLAs were outlined so that students have the opportunity to engage more closely and hands-on with their studies. A greater variety of assessments were described giving students the opportunity to more accurately gauge their own progress through the course through formative assessment, and moving away from examination situations which encourage shallow learning. Through the use of a checklist staff participants were able to ensure that this one specific course stills emphasises the key philosophical underpinnings of the programme as a whole.

\section{Discussion}

Advocates of constructive alignment are many (e.g. $\mathrm{Co}^{-}$ hen, 1987; Biggs, 1996; Biggs \& Tang, 2007; Harden,
Crosby \& Davis, 1999): it is an approach which has strong intuitive appeal. However, there are critics of constructive alignment who argue that its true value has yet to be demonstrated (e.g. Jervis \& Jervis, 2005). Indeed it is true that while a literature search for 'constructive alignment' yields a great many papers, few of these can be considered evaluations of the effectiveness of the approach.

How will the success of our newly aligned HCD course be evaluated? One way in which we plan to evaluate effectiveness is through the use of the student evaluation questionnaire that was described in Phase I of this study. Although the quantitative data from that instrument showed largely positive feedback, the qualitative comments suggested a range of difficulties specifically with TLAs and assessment. The written questionnaire which students completed at the end of the course for evaluation purposes was not designed specifically for the research described here, but is rather a generic student feedback evaluation. More sensitive and specific evaluation materials need to be designed which can take into account aspects of the revised curriculum and constructive alignment, e.g. students might be asked more explicitly for comments about the nature of ILOs, and whether TLAs are helpful in facilitating these. Quantitatively, student grades might be compared pre- and post curriculum changes. However such an exercise may fail to capture the changes that have been brought to the course: the student cohorts who are being compared will be different; the grades may differ because of the marking criteria used and the nature of the assignments. It will be a challenge to know whether it is the explicit alignment itself that may have brought about changes, or the use of more innovative TLA's or indeed more wide-ranging assessments which include formative tasks. Challenges in evaluating the effectiveness of curriculum changes are numerous and may be one of the reasons why there are very few studies which have actually demonstrated the value of constructive alignment in learning outcomes when compared to courses which are for example, not explicitly aligned.

Brabrand (2007) describes positive changes that were brought about through the constructive alignment process in his science course, but these changes centre around his own subjective opinions rather than objective measures of these changes. He notes:

“...it is my experience that...constructive alignment provides... insights on where and how to optimize the teaching system for student learning in making sure the students have the necessary incentive and support for learning. It is also my own personal experience that the course and the quality of the projects handed in by the students improved significantly with alignment." (p.13).

Braband (2007) did evaluate his students' satisfaction with the course pre-and post alignment, and also. includes some qualitative data from student feedback forms - however as has been noted before it is difficult to account for why change occurred and whether it is due to teaching methods and alignment, or the student group itself.

Another criticism of constructive alignment is that the focus on outcomes is too limiting especially in higher educa- 
Table 5: Human Communication Development: Grading Criteria

Grades will depend on how well you can demonstrate that you have met all ILOs:

Excellent performance: In-depth understanding of course content across all ILOs; offers creative information and innovative solutions. Demonstrates that knowledge is supplemented by ongoing and additional reading / observations beyond what is expected in this course. Student has sound knowledge and excellent reasoning to work independently. Shows advanced self-reflection skills and works well in all groups.

Very good performance: Very good understanding of the course content. Comprehensively covers all issues with minimal support from facilitators and takes initiative to provide additional information. Shows awareness of literature and ability to access it independently and use it appropriately. Reasoning skills are developing well and student shows good evidence of self-reflection skills and ability to work in groups.

Good performance: Student demonstrates good understanding of the course content, although some ILOs are met more completely than others. Needs refinement in clinical reasoning, and development of self-reflection skills. Make some attempt to refer to literature but needs to develop knowledge of links between what is read and what is observed; Works well in groups but needs to develop group working skills further and spend more time engaging with learning to develop depth of knowledge in all areas.

Pass, fair performance: Meets ILOs at a minimally acceptable level; understands course content but at minimal depth and may have difficulty linking to literature; or may have specific difficulties with achieving particular ILOs. Reasoning skills and self-reflection skills are adequate at a basic level for the year group and show potential to develop; Group work may be a challenge and the student may rely heavily on others in the group.

Below minimum, competence: Student has not met all ILOs and shows limited or shallow learning; no links to literature; poor or lacking in reasoning and reflection skills; attitudinal issues may be problematic; student will not be adequately prepared to function in a clinical setting; student is able to contribute minimally to group work.

Unsatisfactory: Student has achieved few if any ILOs; learning is shallow and limited; student shows no evidence of reading or awareness of literature beyond course notes; attitudinal issues are noted; student will not be able to function in clinical setting; contributes minimally if at all to group work; self-reflection and reasoning skills are minimal or non-existent

\section{Grade}

$75+$

\section{0-74}

\section{$60-69$}


we felt should be included; TLAs that we felt were suitable or assessments that we were comfortable with. However, focusing on our ILOs was a constant reminder to ask ourselves: what is it we want the students to be able to achieve by the end of this course? And then, in turn, how do content, TLAs and assessment all fit with this? Constructive alignment has given us a theoretical framework for understanding why this particular course - and ultimately the programme as a whole - occurs the way it does. McCune and Hounsell (2005) have gone on to suggest that constructive alignment is a misnomer since constructivism is not necessarily demonstrated in aligned approaches. This may be the case: it is not difficult to imagine how one might end up with an aligned curriculum that is devoid of constructivism. However, our approach has been to explicitly incorporate both 'constructivism' and 'alignment' in our curriculum revision. The explicit inclusion of communal constructivism is one way in which we have assured that constructivism is a part of the curriculum and throughout the curriculum revisions we have strived to have students actively engaging and building their knowledge, e.g. consider the glossary building activities of ILOs 1 and 3 .

While some have described constructive alignment as something which academics typically do already (McCune \& Hounsell, 2005) other authors have acknowledged that constructive alignment is extremely difficult to achieve: Houghton (2004) notes that it is virtually impossible to get it right first time. For this reason reflective practitioners are required, i.e. teachers who constantly adapt course design and delivery, continually moving their course or programme towards (unattainable) perfect constructive alignment. This approach of constantly revising and reworking courses fits with the methodology described here: The revised HCD course will take place in 2009 and it remains to be seen whether the newly aligned course will result in more effective learning for students.

The reflective logs of staff offer some insights into our own perceptions of constructive alignment. Here we share three key themes which emerged from staff logs and highlight the parallels between 'teachers' and 'learners', as the staff participating in this project become learners themselves, grappling with a large body of unfamiliar literature.

Mind the gap: The divide between theory and practice

Much has been written about the difficulties that SLP students and others of related disciplines face when having to make links between the theory that is typically taught in lectures, and 'doing the job' in a clinical setting (Brumfitt, 2004; Grundy, 2004). It should come as no surprise when one considers the different outcomes expected of students in both settings; and given the fact that there are many practising clinicians who battle to bridge this divide - as exemplifiẹd in Claire Penn's editorial response entitled: "Don't give me the theory, just tell me what to do in therapy..." (Penn, 2007). This theory / practice gap was also closely felt by all staff participants as we grappled with the unfamiliar literature of educational theory. All staff were able to grasp the key concepts of the educational literature required for our project, but having achieved this through a set of readings did not mean that we could effortlessly apply the knowledge to revise the curriculum (or indeed in its implementa- tion). Many of the staff participants felt out of their depth and inadequately prepared to do so - despite having done our homework and 'learnt' the theory. Feeling 'inadequate about how to do this'; 'like a back-row girl'; 'completely out of my depth' are all feelings that staff described at the start of the process. These are surely some of the same comments that we will have heard our students make in their clinics. Reflecting on our feelings of uncertainty and how these gradually gave way to a more confident feeling can only serve as a helpful reminder of the challenges that our students face.

One of the key motivators for the curriculum work described in this paper has been to bridge the divide between theory and practice so that the two are able to link more seamlessly with each other. Rather than the sorry state of affairs Penn (2007) described we strive for graduates who will say: "I'll do it... and I can give you the theory that underpins what I do!" One way of moving towards this scenario is to keep our focus on the ultimate outcomes of the programme (Who are those thinking therapists, those agents for change that we want to produce?) and ensure that courses from the very start of the programme work towards that goal. In the revised $H C D$ curriculum described in this paper we have included a range of aspects that work towards this goal. Having clinical educators as well as academic staff involved in the project is another way in which we have attempted to bridge the divide. This was something which almost all staff seemed to express in their comments on the process. The bridging of the gap between theory and practice works both ways: not only should we be introducing practical aspects and clinically-linked skills earlier in the programme, but theoretical aspects should be incorporated explicitly in clinical work in the later years. Students should be able to make reference to appropriate literature and the rapidly expanding evidence base in SLP, when called upon to do so - and for their own peace of mind and professionalism as a matter of course.

\section{Building together: Communal constructivism}

Communal constructivism aims to move beyond social constructivism and sees individuals constructing meaning together not just alongside each other but for each other, working together to create something. In the HCD course we have included some TLAs and assessment tasks which closely follow this principle: students are required to work in small groups with a key aim of the activity being to build materials that can be shared with all present and future students in the division. Intuitively this approach appeals to staff and students alike: the value of resources that are actually needed, used by many and freely available to all who may need them is easy to see. It is more than just doing assignments for a mark, but about contributing in a meaningful and socially responsive way. Our aim is that students from a diverse range of backgrounds will relate to this and find meaning in the assessment activities.

Our own curriculum work resonated with the principles of communal constructivism: the curriculum does not belong to any of us individually, it belongs to all and is something that will be used and modified and for the benefit of current and future students in our programme. Our difficulties in grappling with the theory were given meaning and 


\section{TOWARDS CONSTRUCTIVE ALIGNMENT IN THE SLP CURRICULUM}

purpose when we consider what it is we have jointly constructed. As one staff participant noted:

"If I had taken a test or exam on educational theories and curriculum development after I had just read the chapters and papers on the subject, I would have failed or maybe just scraped a pass... if I reflect back on when I really learnt, it was when we had to produce something [the revised course] and we all started putting the pieces of the puzzle together."

This comment illustrates both components of communal constructivism - the communal reflected in "we all... together" and constructivism in "producing something" or "putting the pieces..." Comments from staff participants also reflected the rewards and challenges associated with working in groups, and many of these comments reflected those of our students, some of whom - just like us- face the prospect of working in groups with dread! In the revised HCD course, the emphasis on group working is clearly shown - it is included as an explicit outcome (e.g. see ILO3 which includes the attitudinal component: 'Develop an appreciation for benefits of working in a group' and carefully aligned TLAs involve opportunity to develop this skill. Working in a group does bring with it unique challenges: it is our belief that the benefits outweigh the challenges and that students (and staff) should be encouraged to develop in this area, especially since part of an SLP's role may well involve facilitating individuals working in groups. Research findings suggest that while students can gain factual knowledge equally effectively by studying individually or by participating in collaborative learning, critical thinking is significantly improved in the latter (Gokhale, 1995). Students perform at higher intellectual levels in cooperative learning situations (Vygotsky, 1978), because problem solving strategies are improved when presented with different interpretations. Further, peer support allows students to convert knowledge and critical thinking skills into tools for intellectual functioning (Bruner, 1985).

\section{A spiral of learning}

An interesting paradox which emerged from some of the staff participants' logs is that while the focus of the curriculum work has been on specifying clearly delineated outcomes, the entire process of curriculum revision does not have a clearly delineated outcome. It will involve ongoing revisions and refinements that mean progress, although it will be necessary to constantly revisit and reflect on what is we are achieving or not achieving. For some this is 'frustrating,' 'daunting' and 'a bit depressing.' Houghton (2004) notes that constructive alignment cannot be achieved or maintained in an institutional system that does not allow frequent modification of module descriptions. For others it reminds us about the lifelong nature of learning: learning can never be finished. This is an important message that we wish to convey to our students: they need to become lifelong learners who are empowered to access information and continually construct their knowledge throughout their lifetime. We cannot teach them everything that they need to know about SLP in four years of study: the best we can do is ensure they meet exit level criteria, and are equipped with an awareness of how to continue developing their knowledge.

\section{The way forward}

First year students will experience the revised $\mathrm{HCD}$ course in the first semester of 2009. The course will be evaluated and modified in light of the feedback received, continuing the spiral of participatory action research. Staff participants continue to work together as a team to modify all courses of the SLP programme using the principles of constructive alignment outlined in this paper. The ultimate aim is for all the courses comprising the SLP programme to be aligned at a micro level, and all courses within the programme to be aligned with each other at a macro level. The curriculum process is not only about alignment; constructive alignment is brought in through an awareness of how best we can ensure students engage with their learning and build their knowledge in an ongoing - and often communal - manner. The example of TLAs and assessment given in this paper show some of the ways in which we aim to achieve this goal.

It is clear that changes to the HCD course will need to be made based on students and educator feedback, as well as the changing needs of the student body and the profession of SLP. We are certain that we will not have achieved perfect constructive alignment right away, but consider that the first attempt described here may be useful to others considering or working through the process themselves.

Acknowledgements: The authors gratefully acknowledge colleagues in the Division of Communication Sciences and Disorders who contributed to this project.

\section{References}

Biggs, J. (1996). Enhancing teaching through constructive alignment. Higher Education, 32, 347 - 364.

Biggs, J. (1999). Teaching for Quality Learning at University, (1 ${ }^{\text {st }}$ Edition). SRHE and Open University Press: Buckingham.

Biggs, J. (2003). Teaching for Quality Learning at University: What the student does ( $2^{\text {nd }}$ Edition). SRHE and Open University Press: Buckingham.

Biggs, J. B. \& Collis, K. F. (1982). Evaluating the Quality of Learning - The SOLO Taxonomy. New York: Academic Press.

Biggs, J. \& Tang, C. (2007). Teaching for Quality Learning at University ( $3^{\text {rd }}$ ed.). SRHE and Open University Press: Berkshire, U.K.

Boud, D. \& Feletti, G. (eds) (1991). The Challenge of Problem Based Learning. London: Kogan-Page.

Braband, C. (2007). Constructive alignment for teaching model-based design for concurrency (a case study on implementing alignment). Invited paper for TeaConc, 2007.

Brown, G. \& Atkins, M. (1988). Effective Teaching in Higher Education. London, Methuen.

Brumfitt, S. (2004). Innovations in Professional Education for Speech and Language Therapy. London: Whurr Publishers.

Bruner, J. (1985). Vygotsky: An bistorical and conceptual perspective. Culture, communication, and cognition: Vygotskian perspectives, 21-34. London: Cambridge University Press.

Chadwick, S. (2004). Curriculum development in orthodontic specialist registrar training: can orthodontics achieve construc- 
tive alignment? Journal of Orthodontics, 31, 267-274.

Cohen, S.A. (1987). Instructional alignment: searching for a magic bullet. Educational Researcher, 16 (8), 16-20.

Colliver, J. (2000). Effectiveness of problem-based learning curricula. Acad Med, 75, 259-266.

D'Andrea, V.M. (1999). Organizing teaching and learning: outcomes-based planning. In Fry, H., Ketteridge, S., Marshall, S. (Eds). A Handbook for Teacbing and Learning in Higher Education: Enbancing Academic Practice. London: Kogan, Pp. 41-58.

Davies, P. \& van der Gaag, A. (1992). The professional competence of speech therapists I: Introduction and Methodology. Clinical Rebabilitation, 6, 209-214.

Dolmans, D. \& Schmidt, H. (1994). What drives the student in problem-based learning? Medical Education, 28 (5), 372-380.

Doolittle, P. E. (1999), "Constructivism: The Career and Technical Education Perspective." Journal of Vocational and Technical Education, 16, (1).

Fosnot, C. T. (1996). Constructivism: Theory, perspectives, and practice. New York: Teachers College Press.

Gokhale, A.A. (1995). Collaborative learning enhances critical thinking. Journal of Technology Education, 7(1), 22-30.

Grundy, K. (2004). Peer placements. Chapter in S. Brumfitt (Ed), Innovations in Professional Education for Speech and Language Therapy. Whurr Publishers.

Gultig, J., Lubisi, C., Parker, B. \& Wedekind, V. (1998). Understanding outcomes-based education. Teaching and assessment in South Africa. Cape Town: Oxford University Press.

Hamilton, J. (1999). Outcomes in medical education must be wide, long and deep. Med Teach, 21, 15-22.

Hammel, J., Royeen, C., Bagatell, N., Chandler, B., Jensen, G, Loveland, J. \& Stone, G. (1999). Student perspectives on problem-based learning in an occupational therapy curriculum: a multiyear qualitative evaluation. American Journal of Occupational Therapy, 53 (2), 199-206.

Harden, R., Crosby, J. \& Davis, M. (1999). An introduction to outcome-based education, Medical Teacher, 21(1), pp. 7-14.

Health Professions Council of South Africa (HPCSA) (2003). Report of the ad-hoc committee on the competency profile of speech-language therapists and audiologists. Professional Board for Speech-Language and Hearing Professions. South Africa.

Holmes, B., Tangney, B., FitzGibbon, A., Savage, T \& Meehan, S (2001). Communal Constructivism: Students constructing learning for as well as with others. Proceedings of SITE 2001, Florida

Houghton, W. (2004) Engineering Subject Centre Guide: Learning and Teaching. Theory for Engineering Academics. Loughborough: HEA Engineering Subject Centre.

Irving, Z. \& Young, P. (2005) When Less is More: The Dominance of Subject-Content in the Teaching of Undergraduate Social Policy. Social Policy and Society, 4, 1-9.

Jervis, L.M. \& Jervis, L. (2005). What is the constructivism in constructive alignment? $B E E-j 6$ (5), 1-14.

Kamhi, A. (1995). Research to Practice. Defining, developing and maintaining clinical expertise. Language Speech and Hearing Services in Schools, 26, 353-356.

Khan, F., Campbell, N. \& Louw, B. (2007). Auditory Processing Disorders: Training of Speech-Language Therapists within the South African Context. South African Journal of Communication Disorders, 54, 77-89.
Kritzinger, A. \& Louw, B. (2003). Clinical Training of Undergraduate Communication Pathology Students in Neonatal Assessment and Neonate-Caregiver Interaction in South Africa. South African Journal of Communication Disorders, 50, 5-14.

McAllister, L., Lincoln, M., McLeod, S \& Maloney, D. (1997). Facilitating learning in Clinical Settings. Cheltenham: Stanley Thornes.

McCune, V. \& Hounsell, D. (2005). The development of students' ways of thinking and practising in three final-year biology courses. Higher Education, 49, 255- 289.

Nandi, P., Chan, J. \& Chan, C. (2000). Undergraduate medical education: comparison of problem-based learning and conventional teaching. Hong Kong Med J, 6, 301-306.

Pascoe, M., Stackhouse, J., \& Wells, B. (2006). Persisting Speech Difficulties in Cbildren (Children's Speech and Literacy Difficulties Series, Book 3). Wiley Ltd: Chichester.

Penn, C. (2007). "Don't give me the theory, Just tell me what to do in therapy!": The Slippery slope challenge for the South African professions of Speech-Language Pathology and Audiology. South African Journal of Communication Disorders, 54, 13-17.

Reason, P. \& Bradbury, H. (Eds.) (2001). Handbook of Action Researcb: Participative Inquiry and Practice. Sage: Thousand Oaks, CA.

Savin-Baden, M. \& Wilkie, K. (2004). Challenging Research in Problem-based Learning. Buckingham: Society for Research into Higher Education and Open University Press.

Stengelhofen, J. (1993). Teaching students in clinical settings. Cheltenham: Stanley Thornes.

Tan, K., Lee, M, Mok, J. \& Ravindran, R. (2005). Problem-based learning: New directions and approaches. Learning Academy: Temasek Polytechnic.

Toohey, S. (1999). Designing courses for Higher Education. Buckingham: Society for Research into Higher Education and Open University Press.

Vygotsky, L. (1978). Mind in society: The development of higher psychological processes. Cambridge: Harvard University Press.

Whitworth, A., Franklin, S. \& Dodd, B. (2004). Case-based problem solving for SLT Students. Chapter in S. Brumfitt (Ed), Innovations in Professional Education for Speech and Language Therapy. Whurr Publishers: London. 
Appendix 1. Unrevised version of the Human Communication Development course

\section{COURSE AIMS:}

1 . To build on the knowledge of [psychology course] and to link this to normal communication development across the human life span.

2. To provide a comprehensive working knowledge of normal speech, language and hearing development from birth, through the infant-, toddler-, pre-school and school-age phases.

3. To develop a sound understanding of the nature and development of phonology, syntax, morphology, semantics, pragmatics, meta-linguistic abilities and literacy.

4. To present an overview of the significant issues pertaining to the cultural diversity in South Africa and their impact on our understanding of normal communication development.

\section{COURSE OBJECTIVES;}

1. Knowledge: At the end of the course the student will be expected to;

a. Describe the nature of human communication.

b. Describe the principles and patterns of normal speech, language and hearing development.

c. Describe the significant milestones in normal speech, language and hearing development across the human lifespan.

d. Define and describe the domains and development of phonology, syntax, morphology, semantics, pragmatics, meta-linguistic abilities and literacy.

e. Outline the issues involved in the establishment of relative developmental norms.

f. Outline the issues of linguistic and cultural diversity in the South African context, and their

i. relevance to the description and assessment of normal communication development

2. Skills:

ii. implications for interventions in multi-lingual contexts.

In preparation for clinical practice, the student should be able to;

a. gauge significant milestones in normal speech, language and hearing development, with consideration of relevant issues of diversity.

b. discern non-negotiable universals versus contextual variables in speech, language and hearing development.

c. identify and access methods of community resource mapping for the development of culturally appreciative, criterion referenced communication development profiles.

d. collaborate with caregivers to negotiate relevant expectations of communication development.

3. Attitude: The student should be able to appreciate and apply learning of;

a. The whole-person approach: that is; speech, language and hearing development in the context of

i. the child's general development.

ii. the child's environmental context.

b. Diversity issues (contextualization, appreciation of socio-cultural impacts, etc). 
MICHELLE PASCOE \& SHAJILA SINGH

Appendix 2: A Blank Template for facilitating curriculum alignment

\begin{tabular}{|c|c|c|c|}
\hline $\begin{array}{l}\text { 1. Intended Learning Outcome } \\
\text { (ILO) }\end{array}$ & $\begin{array}{l}\text { 2. Content } \\
{ }^{\star} \text { Minimal depth } \\
{ }^{\star \star} \text { Moderate depth } \\
{ }_{\star \star \star} \text { Most in-depth topic }\end{array}$ & $\begin{array}{l}\text { 3. Teaching and Learning } \\
\text { Activities }\end{array}$ & 4. Assessment \\
\hline $\begin{array}{l}\text { ILO1: } \\
\text { Knowledge: Level: } \\
\qquad \text { Type: } \\
\text { Skills: } \\
\text { Attitudes: }\end{array}$ & & & \\
\hline 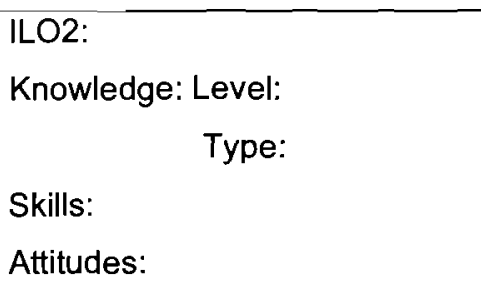 & & & \\
\hline $\begin{array}{l}\text { ILO3: } \\
\text { Knowledge: Level: } \\
\qquad \text { Type: } \\
\text { Skills: } \\
\text { Attitudes: }\end{array}$ & & & \\
\hline $\begin{array}{l}\text { Checklist: } \\
\text { Key Themes: } \\
1 . \\
2 . \\
3 .\end{array}$ & Included & & \\
\hline
\end{tabular}




\section{NATURE OF PUBLICATION}

The South African Journal of Communication Disorders publishes reports and papers concerned with research, and critically evaluative theoretical and philosophical conceptual issues dealing with aspects of human communication and its disorders, dysphagia, service provision, training and policy. The Journal will accept the following three types of manuscripts:

- Research manuscripts defined as reports based on qualitative or quantitative research.

- Original general manuscripts which are reports of work usually, but not exclusively, theoretical in nature and regarded as providing a significant, critically evaluative contribution to the field of human communication and its disorders and/or dysphagia.

- Review manuscripts which are usually written by authors invited by the Journal's editorial team to comment, express opinions and or critically evaluate a topic.

The Journal will not accept material which has been published elsewhere or that is currently under review by other publications.

\section{MANUSCRIPT SUBMISSION \& STYLE REQUIREMENTS}

- Manuscripts must he accompanied by a covering letter providing the author's address, telephone and fax numbers and e-mail address.

One electronic copies of the manuscript must be submitted to the SASLHA office manager for the Editor-in-Chief (email: admin@saslha.co.za).

The title page of the manuscript must contain:

- Title of the manuscript.

Full name(s) of the author(s).

Institutional affiliation, postal address, full contact details.

Abstract of the manuscript in English. If the language of the manuscript

is not in English then an additional abstract in the language the manuscript must be included.

The manuscript copies must not contain any statements/features that identify the author(s) names, institutional affiliations or any other details that reveals the identity of the author(s).

The filename must include the first author's initials and a clearly identifiable key word and must he type-written on the last line of the last page of the Reference list (for retrieval purposes only).

The Editor-in-Chief and/or the South African Speech-Language-Hearing Association (SASLHA) office manager will acknowledge receipt of the manuscript within a maximum of 7 days. If at this stage, no acknowledgement has been received by the author, the author is kindly requested to follow this up with the SASLHA office.

MS Word must be used for the text. MS Word or MS PowerPoint should be used for figures, and MS Excel for tables.

Manuscripts must be in double spacing and in a font size of 12 .

Manuscripts must be on A4 pages in double spacing and in a font size of 12

Filenames must include the first author's initials and a clearly identifiable key word.

Manuscripts must not exceed 30 pages.

The order of the manuscript should be: title page, abstract and key words, text, references, tables, legends, and figures.

Each manuscript must contain an English abstract of no more than 200 words with 5-7 key words.

Strict adherence to the Publication Manual of the American Psychological Association ( $5^{\text {th }}$ ed., 2001) is required.

Headings are NOT NUMBERED. The order of importance is indicated as follows:

- Main heading in capitals and bold print.

- Sub-headings in capitals, bold and italic print

- Sub-subheadings in upper and lower case bold and italic print.

- Sub-sub-sub-heading in upper and lower case bold print.

Major headings, where applicable, must be in the order of INTRODUCTION, METHOD, RESULTS, DISCUSSION, CONCLUSION, ACKNOWLEDGEMENTS, and REFERENCES.

All paragraphs should be indented.

All tables, figures and illustrations must be numbered and provided with titles. The title of tables, which appear above, and of figures, which appear below, must be concise but explanatory.

Allow for $50-75 \%$ reduction in printing of tables, figures and illustrations.

Each table, figure or illustration must appear on a SEPARATE page.

Do not include more than 10 tables, figures or illustrations.

Colour graphics are NOT preferred. If submitted, extra cost of colour reproduction and printing must be covered by the author prior to publication. A short running title should be listed at the top left-hand corner of the title page. Any information about grants or other financial support should be supplied as an unnumbered footnote to the manuscript title.

Graphics, audio and/or video files (not exceeding $2 \mathrm{MB}$ ) may be submitted for future publication as an electronic online Journal. Consult the Editor-in-Chief regarding required file formats.

Authors must use gender-, race-, and creed-inclusive language.

Authors must ensure adherence to national and/or international ethical codes. British spelling (e.g. centralise not centralize, behaviour not behavior) is preferred.

\section{REFERENCING}

References must be cited in the text by author's name and the date, e.g. Van Riper (1971).

Where there are more than two authors, after the first occurrence, et al. may be used.

The names of all authors must appear in the Reference List, which must be listed in strict alphabetical order in triple spacing at the end of the manuscript.

All references must be included in the List, including secondary sources.

Only acceptable abbreviations of journals may be used, (see DSI-1 ABSTRACTS, October; or The World List of Scientific Periodicals).

Author(s) should use references that reflect an international diversity among authors of both source articles and cited articles.

The number of references should not exceed 30 , unless specifically warranted

\section{EXAMPLES}

Locke, J.L. (1983). Clinical Psychology: The explanation and treatment of speech sound disorders. J. Speech Hear Disord., 48 339-341.

Penrod, J.P. (1985). Speech discrimination testing. In J. Katz (Ed.), Handbook of clinical audiology ( $3^{\text {id }}$ ed.). Baltimore: Williams \& Wilkins.

Davis, G. \& Wilcox, M.J. (1985). Adult aphasia rehabilitation: Applied pragmatics. San Diego, CA: College-Hill.

\section{EDITING}

Manuscripts must be corrected for grammar and style prior to submission.

Only manuscripts complying with the above requirements will be accepted for review.

\section{REVIEWING SYSTEM}

The double-blind peer review system is employed as a method of quality control of this publication and ensures that author(s) and reviewers do not know each others' names.

Each manuscript is sent to two independent reviewers, selected according to their area of expertise, to assess the quality of the manuscript's scientific and technical content.

Author(s) must ensure that the manuscript does not contain information/clues as to the identity of the author(s).

The Editor-in-Chief retains the final responsibility for decisions regarding revision, acceptance or rejection of the manuscript. This process is usually done in consultation with the manuscript's editor and/or the editorial team, as necessary.

\section{DEADLINE FOR CONTRIBUTIONS. $28^{\text {th }} / 29^{\text {th }}$ February each year}

PUBLICATION FEE: Authors will be expected to pay a publication fee. The exact amount is determined by printing costs.

QUERIES AND CORRESPONDENCE: should be addressed to The Editor-inChief, South African Joumal of Communication Disorders, South African SpeechLanguage-Hearing Association, PO Box 10813, Linton Grange, 6015, South Africa. Email SASLHA at admin@saslha.co.za for the current Editor-in-Chief's email address.

Author's Responsibility: The South African Journal of Communication Disorders is not responsible for authors' views and does not endorse any of the products or materials advertised in the Journal.

Copyright: The copyright of all manuscripts printed in The South African Journal of Communication Disorders is reserved by The South African Speech-LanguageHearing Association (SASLHA).

2008 Editorial Team

Editor-in-Chief

Editors

Eleanor Ross

Technical Editor:

Layout \& Design:

Mrs Claudine Emmerick

Publication Manager: Mrs Diane Hoctor
Dr Mershen Pillay

AJProf Harsha Kathard, Dr Michelle Pascoe, Prof 